\title{
Qualitative assessment of sediment from River Meghna, Bangladesh
}

\author{
M. S. Bhuyan* and M. S. Islam \\ Institute of Marine Sciences and Fisheries, University of Chittagong, Chittagong, Bangladesh
}

Received: 27 February 2017

Revised: 25 Janurary 2018

Accepted: 31 Janurary 2018

DOI: http://dx.doi.org/10.3329/bjsir.v53i2.36669

\begin{abstract}
The present study was conducted to find the status of different soil quality variables of the Meghna River during the period from September, 2015 to March, 2016. The values of different soil quality parameters such as silt, sand, clay, bulk density, $\mathrm{pH}, \mathrm{EC}$ and organic matter fluctuated between $13.33-58.33 \%, 29.25-88.42 \%, 4.92-17.42 \%, 1.43-1.71 \mathrm{~g} / \mathrm{cm}^{3}, 6.86-8.06,43-942.67 \mu \mathrm{s} / \mathrm{cm}$ and $0.24-3.1 \%$ respectively. The heavy metals were analyzed by Atomic Absorption Spectrophotometer (AAS). The observed order of heavy metals mean concentration in sediments $\mathrm{Fe}>\mathrm{Pb}>\mathrm{Cr}>\mathrm{Co}>\mathrm{Cd}$ in $\mathrm{mg} / \mathrm{kg}$, respectively. Significant differences $(\mathrm{p}<0.05)$ was found in the values of soil organic matter of the Meghna river in terms of sites. But the value of silt, sand, clay, bulk density, $\mathrm{pH}$ and $\mathrm{EC}$ exhibited no significant variation with sites. The concentration of silt, sand, clay, bulk density, $\mathrm{pH}, \mathrm{EC}$ and organic matter showed no significant variation with seasons $(\mathrm{p}>0.05)$. Very strong positive correlation between Cr vs EC (0.965), Cd vs EC (0.962), Cd vs Cr $(0.959)$ and bulk density vs \% sand (0.951) was observed at the significance level 0.01 . Fe vs \% sand (0.944), Cd vs Fe (0.824), Pb vs \% O.M (0.823) and bulk density vs Fe (0.822) showed very strong positive correlations at 0.05 level of significance. The concentration of the soil parameters indicate that the river is being polluted and the statistical analysis proved that anthropogenic sources are the main contributor.
\end{abstract}

Keywords: Sediment quality; Parameters; Fluctuate; Correlation matrix; Meghna river

\section{Introduction}

The quality of soil is the ability to supply essential nutrient components to the plants in suitable extent and in adequate proportion for their optimum growth, support human health and habitation (Larson and Pierce, 1991; Suresh and Nagesh, 2015). Such kind of qualitative soil contain biological elements that are key to ecosystem functions (Doran et al., 1996) and productivity of soil that maintain the quality of surrounding air and water, as well as promote plant, animal and human health (Doran and Zeiss, 2000). Quality soil provide fresh air and water, plentiful crops and forests, diverse wildlife and beautiful landscape (Karlen et al., 1997). Soil quality has constantly changed with an upsurge in the understanding of soils and soil quality features. Soil quality can be measured through indicators of oil properties that are sensitive to changes in management (Andrews and Cambardella, 2004). A large number of soil function dependent indicators are used for the assessment of soil quality (Bone et al., 2010). In the humid tropics, spatial and temporal variability in the quality of soils is pronounced due to variable land uses (Onweremadu et al., 2006; Onweremadu, 2007).

Indicators differ according to the place and the level of complexity of measurements (Riley, 2001). The dynamic quality of soil controlled by physical, chemical and biological components and their interactions which can affect its sustainability and productivity (Parpendick and Parr, 1992). Among physical, chemical, and biological components, biological indicators of soil are critically important (Abawi and Widmer, 2000). Since soil quality is strongly influenced by nutrient cycling, nutrient capacity and aggregate constancy. Biological indicators measured usually include soil organic matter and mineralizable nitrogen which play an important role in soil function, soil quality determination, water holding capacity and susceptibility of soil to degradation and soil organic matter (Giller and Cadisch, 1996; Lal et al., 1997). 
Soil quality information is needed to help farmers to know the chain of causes and effects that connect farm decisions to ultimate productivity indicators and health of plants and animals. The quality of soil depends on agricultural use (Andrews and Carroll, 2001); where attention is paid to plant and animal productivity in cultivated soils (Liebig et al., 1996), as opposed to urban soils (Idowu and Van, 2007). Nutrient imbalance in soil, excessive fertilization, soil pollution and soil loss processes exert adverse effects on soil quality (Zhang et al., 1996; Hedlund et al., 2003). Food production is decreasing in Africa due to loss or reduction in soil quality which can also affect the maintenance of the quality of adjacent air and water environments (Karlen et al., 1997; Lal et al., 1997). Variation in nutrient concentration across landscape has become the pivotal point of many ecological research (Benning and Seastedt, 1995). Spatial variation of soil quality and ultimate productivity is largely affected by farming, sand dredging, compaction of soil, and other anthropogenic activities. The soil quality assessment is necessary to assess the degradation status and changing trends (Lal and Stewart, 1995). In the developing world, soil quality investigation under intensive land-use and fast economic development is a major challenge for sustainable resource use (Doran et al., 1996). This study, therefore, conducted to investigate the extent of temporal and spatial variation and level of soils quality of the Meghna River.

\section{Materials and methods}

\section{Sampling sites}

Sediment samples were collected form two sites: Effluent discharged area (Boro Bazar) and far away from the discharged area (Boiddamar Char) of the Meghna River near Narsingdi District (Fig. 1). Sampling procedures were performed in three phases: firstly, September, 2015 (Rainy

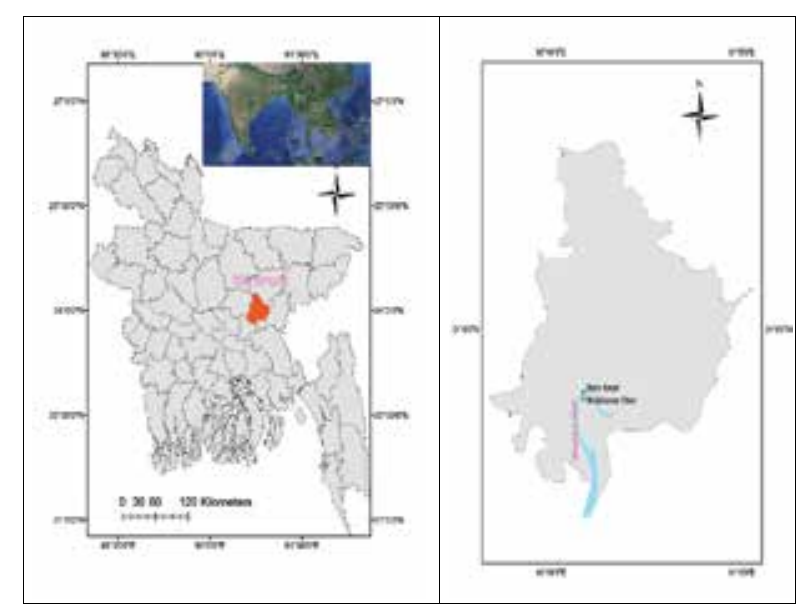

Fig. 1. Map showing sampling points of the Meghna River (Map created by ArcGIS v.10.3) season); secondly, January, 2016 (Winter season) and thirdly, March, 2016 (Pre-monsoon).

\section{Sample collection}

After selection of sampling points, a total of 12 sediment samples were collected. 6 sediment samples were collected from industrial impacted site and rest 6 samples were collected from the pristine area $(3 \mathrm{~km}$ away from industrial zone). Immediately after collection, sediment sample were transferred to the laboratory of Department of Soil Science, University of Chittagong, Chittagong, Bangladesh.

\section{Assessment of soil quality}

Soil samples were collected from the study area by using transect method along with stratified random technique (Hale, 2013). For soil sampling, three transects maintaining distances of $1 \mathrm{~km}$. Two sites of river located in each transect were chosen maintaining an equidistance from one to another for the collection of soil sample. A hand held cylindrical corer (length: $30 \mathrm{~cm}$, diameter: $3.7 \mathrm{~cm}$ ) was used for the collection of three replicated samples from each sites of the river following ' $\mathrm{S}$ ' shaped design. The collected soil samples were air dried, powdered and passed through a $0.5 \mathrm{~mm}$ mesh sieve. Before analysis, soil samples were finally dried in an oven at $105^{\circ} \mathrm{C}$ for $24 \mathrm{hr}$ except for organic matter sample (samples were air dried). Soil $\mathrm{pH}$ was recorded in-situ condition. Soil $\mathrm{pH}$ was determined by Hanna soil $\mathrm{pH}$ meter (Islam et al., 2016). EC was determined by Hanna EC meter (Mondol et al., 2013), Soil Organic Matter (SOM) was measured by Walkey and Black wet oxidation. Soil texture (\% of sand, silt and clay) in the study area was analyzed by the hydrometer method described by Huq and Alam (2005), modified from Bouyoucos (1936). Soil bulk density was determined by the method described by Huq and Alam (2005). Soil sample was also collected by $5.3 \mathrm{~cm}$ long and $1.9 \mathrm{~cm}$ diameter plastic core for bulk density determination (Huq and Alam, 2005). The heavy metal contents of collected sediments were determined by AAS (Model-iCE 3300, Thermo Scientific) and by complying standard procedures (APHA, 1995). Soil was digested following Acid Digestion Method (Bhuyan and Bakar, 2017)

\section{Data analysis}

One Way Analysis of Variance (ANOVA) test was performed to find out the significant variation among different soil variables measured from different sites in different seasons. A correlation matrix was executed to show the relationship among different soil variables. Graph was produced using SPSS (v.22) to show significant variations among soil quality variables. 


\section{Results and discussion}

Soil fertility is the constituent of soil quality (Hou et al., 2014; Kong, 2014; Toth et al., 2013). Fertile soils provide the nutrients essential for plant growth. In the present study the values (average \pm SD) of different soil quality indicators like silt, sand, clay, bulk density, $\mathrm{pH}, \mathrm{EC}$ and organic matter of the sediment of the Meghna River situated at different sites are presented in details in Table I. The well-balanced concentrations of sand, silt and clay allow for water retention and drainage, oxygen in the root zone, nutrients to simplify crop growth; and they deliver physical support for plants (Jenny, 1941). In monsoon season silt and loam were predominant in the polluted site while sandy and loam soil were found in the non-polluted site (Table I). Sandy soil pattern was found during post-monsoon in the polluted site
$1.04-4.36 \%$ and $67.88-81.37 \%$ in Rajakhali Canal of the Karnaphuli River. Islam et al. (2016) found the percentage of silt and sand fluctuated between $32.73-51.47 \%$ and $6.17-41.09 \%$ at the coastal shrimp culture pond at Chakaria, Cox's Bazar. The percentage of clay ranged between 4.92-17.42 at two sites (polluted and non-polluted) of the river during different seasons. Substantial changes in the concentration of clay was found during pre-monsoon than monsoon and post-monsoon at the polluted (7.42 \pm 1.44$)$ and non-polluted (17.42 \pm 1.44$)$ site (Table I). The soil of the Meghna River was mostly sandy loam, silt loam and loam (Table I). This variation was found in the soil parameters emphasize that the river bottoms were uneven in soil quality. The difference could have been formed by sedimentation processes during the past sewage swamp system (Rahman, 1992; Barua and Zamal, 2011; Venkatramanan et al., 2013a, b; Hossain et al., 2014).

Table I. Soil quality variables of the Meghna River

\begin{tabular}{|c|c|c|c|c|c|c|c|c|c|}
\hline Seasons & Sites & $\begin{array}{l}\text { Textural } \\
\text { Class }\end{array}$ & $\%$ Silt & $\%$ Sand & $\%$ Clay & $\begin{array}{l}\text { Bulk Density } \\
\left(\mathrm{g} / \mathrm{cm}^{3}\right)\end{array}$ & $\mathrm{pH}$ & $\mathrm{EC}(\mu \mathrm{s} / \mathrm{cm})$ & $\% \mathrm{O} . \mathrm{M}$ \\
\hline \multirow{2}{*}{ Monsoon } & Polluted & $\begin{array}{l}\text { Silt } \\
\text { Loam }\end{array}$ & $58.33 \pm 1.44$ & $29.25 \pm 2.5$ & $12.42 \pm 1.44$ & $1.46 \pm 0.02$ & $8.06 \pm 0.29$ & $64.13 \pm 3.32$ & $3.1 \pm 0.22$ \\
\hline & $\begin{array}{l}\text { Non - } \\
\text { polluted }\end{array}$ & $\begin{array}{l}\text { Sandy } \\
\text { Loam }\end{array}$ & $15 \pm 0.0$ & $77.58 \pm 1.44$ & $7.42 \pm 1.44$ & $1.63 \pm 0.03$ & $6.99 \pm 0.02$ & $43 \pm 4.37$ & $0.52 \pm 0.08$ \\
\hline \multirow{2}{*}{$\begin{array}{l}\text { Post } \\
\text { monsoon }\end{array}$} & Polluted & Sandy & $6.67 \pm 2.89$ & $88.42 \pm 1.44$ & $4.92 \pm 1.44$ & $1.71 \pm 0.05$ & $7.95 \pm 0.01$ & $942.67 \pm 28.11$ & $2.58 \pm 0.15$ \\
\hline & $\begin{array}{l}\text { Non - } \\
\text { polluted }\end{array}$ & $\begin{array}{l}\text { Loamy } \\
\text { Sand }\end{array}$ & $13.33 \pm 1.44$ & $80.92 \pm 1.44$ & $5.75 \pm 0.0$ & $1.67 \pm 0.0$ & $7.24 \pm 0.04$ & $108.83 \pm 5.57$ & $0.29 \pm 0.15$ \\
\hline \multirow{2}{*}{$\begin{array}{l}\text { Pre- } \\
\text { monsoon }\end{array}$} & Polluted & $\begin{array}{l}\text { Sandy } \\
\text { Loam }\end{array}$ & $37.5 \pm 25$ & $55.08 \pm 1.44$ & $7.42 \pm 1.44$ & $1.58 \pm 0.03$ & $6.86 \pm 0.03$ & $290.67 \pm 7.37$ & $1.43 \pm 0.0$ \\
\hline & $\begin{array}{l}\text { Non - } \\
\text { polluted }\end{array}$ & Loam & $40 \pm 2.5$ & $42.58 \pm 1.44$ & $17.42 \pm 1.44$ & $1.43 \pm 0.02$ & $7.26 \pm 0.06$ & $59.47 \pm 2.55$ & $0.24 \pm 0.09$ \\
\hline
\end{tabular}

and loamy and was recorded in the non-polluted site. Sandy and loam soil was found in the contaminated site in the pre-monsoon whereas loam soil was recorded from the reference site (Table I).

The concentration of silt and sand varied between 13.33-58.33\% and 29.25-88.42\% (Table I). During monsoon the silt and sand concentration was $58.33 \pm 1.44$ and $29.25 \pm 2.5$ in the polluted site and $15 \pm 0.0$ and $77.58 \pm 1.44$ was in the pollution free site. Minor variation in the concentration of silt and sand was recorded during post-monsoon at both the site (Table I). Islam et al. (2015) recorded silt and sand particles fluctuated from
Bulk density of the present study was recorded between 1.43-1.71 $\mathrm{g} / \mathrm{cm}^{3}$ (Table I). The highest bulk density $\left(1.71 \pm 0.05 \mathrm{~g} / \mathrm{cm}^{3}\right)$ was recorded at the polluted site during post-monsoon and the lowest $\left(1.43 \pm 0.02 \mathrm{~g} / \mathrm{cm}^{3}\right)$ was recorded from non-polluted site during pre-monsoon (Table I). Townsend (1982) reported that soils rich in organics and some friable clay may have a bulk density well below 1 $\mathrm{g} / \mathrm{cm}^{3}$. The present result is far above the result mentioned by Townsend (1982). Islam et al., (2016) found soil bulk density fluctuated between 0.83 to $1.05 \mathrm{~g} \mathrm{~cm}^{-3}$ at the ponds of different tide marks. Typical values of bulk density for soil shown in Table II. 
The value of soil $\mathrm{pH}$ fluctuated between (6.86-8.06) during different seasons at two sites (Table I). Maximum $\mathrm{pH}$ was found 8.06 from the polluted site during monsoon whereas the minimum was 6.86 also recorded from polluted site during pre-monsoon (Table I). This results fully acquiesced with Islam et al., (2016). Mondol et al., (2013) reported that the average $\mathrm{pH}$ value was 6.7 and 6.5 during wet and dry season at the vicinity of the Tejgaon industrial area adjacent to Dhaka City Corporation. Njoku (2013) recorded the $\mathrm{pH}$ variation (5.57-6.52) in the Niger Delta Region of Nigeria. Bottom soil $\mathrm{pH}$ can range from less than 4 to more than 9 but the best $\mathrm{pH}$ for soils is considered to be about neutral pH 7 (Boyd, 1995). Maximum availability of soil phosphorus usually occurs at about $\mathrm{pH}$ between 6 and 7.5 (CFA, 1995). Most soil microorganisms, and especially soil bacteria, function best at pH 7 to 8 (Boyd, 1995). In the present study the highest amount of Electrical Conductivity (EC) was recorded 942.67 $\mu \mathrm{s} / \mathrm{cm}$ at polluted site during post-monsoon. The lowest concentration of EC was recorded $43 \mu \mathrm{s} / \mathrm{cm}$ at non-polluted in the Eastern Cape (Hall and Du Plessis, 1979), the Riet River in the Free State (Van der Merwe, 1965), the Berg and Breede Rivers in the Western Cape (Cass, 1986) and the Vaalharts Irrigation Scheme in the Northern Cape (Streutker et al., 1981). High levels of salinity has negative effect on soil quality and crop yield (Rensburg et al., 2011). Soil organic matter have exert great influences on the chemical, biological, and physical properties of the soil beneficial to crop production (Dexter and Bird, 2001; Pagliai and Vignozzi, 2002; Wosten et al., 1999)). The percentage of soil organic matter ranged between $0.24-3.1 \%$ which is far below the ideal soil organic matter of 5\% (Cragin, 2013) (Table I). The greatest amount 3.1 \pm 0.22 was documented from the polluted site during monsoon while the low concentration was recorded $0.24 \pm 0.09$ at non-polluted site during pre-monsoon (Table I). This low amount of organic matter content also indicate low total nitrogen content in the soil. Mondol et al. (2013) recorded the amount of organic matter $4.87-11.55 \%$ at the vicinity of the Tejgaon industrial area adjacent to Dhaka City Corporation. Organic matter was

Table II. Typical values of organic matter and bulk density for the 12 FAO/USDA soil texture classes (Dexter, 2004)

\begin{tabular}{ccc}
\hline FAO/USDA texture class & Organic Matter $(\%)$ & Bulk Density $\left(\mathrm{Mg} \mathrm{m}^{-3}\right)$ \\
\hline Clay & 4.47 & 1.249 \\
Sand, clay & 3.61 & 1.334 \\
Silt, clay & 3.85 & 1.309 \\
Clay, loam & 3.22 & 1.376 \\
Silt, clay, loam & 3.22 & 1.376 \\
Sand, clay, loam & 2.89 & 1.414 \\
Loam & 2.41 & 1.474 \\
Silt, loam & 2.26 & 1.492 \\
Silt & 1.83 & 1.552 \\
Sand, loam & 2.07 & 1.518 \\
Loam, sand & 1.78 & 1.559 \\
S and & 1.73 & 1.566 \\
\hline
\end{tabular}

site during monsoon (Table I). Mondol et al. (2013) recorded the amount of EC $25-551 \mu \mathrm{s} / \mathrm{cm}$ at the vicinity of the Tejgaon industrial area adjacent to Dhaka City Corporation. Soil EC is a measure of the quantity of salts in soil (salinity of soil). Salinisation of water resources in many area of the world is a great concern for irrigation. Problems associated with salinity in irrigated agriculture had been encountered in some of the areas viz: the irrigation schemes of the Fish and Sundays Rivers found to increase cation exchange capacity that aided in the decomposition of dead algae, consume oxygen and release toxic gas like $\mathrm{CO}_{2}, \mathrm{H}_{2} \mathrm{~S}$ and $\mathrm{NH}_{3}$ (Colt and Armstrong, 1981; Boyd, 1995; Camargo et al., 2005). Loveland and Webb (2003) studied on many literature and failed to identify a critical lower threshold of soil organic matter for sustained soil functions. Optimum values of organic matter for soil shown in Table II. 
Heavy metal concentration is controlled mainly by the textural composition of the sample, i.e., fine-grained sediments contain higher concentrations of trace metals than sand-dominant sediments (Hossain et al., 2014; Dar, 2014; Venkatramanan et al., 2014a, b; Machender et al., 2014; Rajganapathi et al., 2013). Iron (Fe) was ranged between 737-2385 $\mathrm{mg} / \mathrm{kg}$ (Table III). The maximum value was recorded $2385 \mathrm{mg} / \mathrm{kg}$ in polluted area during monsoon lower than the concentration was found by Balkis et al. (2010) from Gokova Bay, Turkey. The lowest amount was 737 $\mathrm{mg} / \mathrm{kg}$ found during monsoon season at the polluted site (Table III). Highest value $(6.98 \mathrm{mg} / \mathrm{kg})$ of $\mathrm{Pb}$ was recorded in the polluted area during the post-monsoon at polluted site that is similar to Begum et al. (2009). Ahmad et al. (2010) reported that maximum value of $\mathrm{Pb}(77.13 \mathrm{mg} / \mathrm{kg})$ was found in sediment from the Buriganga River during pre-monsoon. The low concentration $(2.35 \mathrm{mg} / \mathrm{kg})$ was found during monsoon at non-polluted site (Table III). Very low concentration can affect brain and nervous system, chronic kidney disease and probably cancer (ATDSR, 2007; IARC, 2006). Guideline values for metals in soils shown in Table IV. Soils affected by high amount of chromium $(\mathrm{Cr})$ can be quite complex (Palmer and Wittbrod, 1991; Pagilla and Canter, 1999), Maximum value (6.81 mg/kg) of $\mathrm{Cr}$ was found from polluted area during post-monsoon season (Table III). The concentration is higher than the results stated by Balkhair and Ashraf (2016) and Brady and Weil (1996). The minimum concentration $(1.27 \mathrm{mg} / \mathrm{kg})$ was recorded during monsoon at non-polluted site (Table III). Guideline values for $\mathrm{Cr}$ in soils shown in Table IV.
Cobalt $(\mathrm{Co})$ is essential element to human health (e.g. vitamin B12) but in excess amounts can cause serious effects to lungs and heart (ATSDR, 2004). The transmission potential from soil to the palatable parts of plants is rather low (Luo et al., 2010). In the present study the supreme value of Co was found $0.86 \mathrm{mg} / \mathrm{kg}$ in impacted site during post-monsoon that is far below than the results of Topcuoglu et al. (2004) and Balkis et al. (2007). The minimum value of Co was found $0.20 \mathrm{mg} / \mathrm{kg}$ from non-polluted area during monsoon season (Table III). Guideline values for Co in soils shown in Table IV. Cadmium (Cd) come into the human body through the food materials that accumulate $\mathrm{Cd}$ from the soil. Soil protection actions are needed to improve the present state by preventing any further $\mathrm{Cd}$ contamination e.g. by controlling $\mathrm{Cd}$ in phosphorus fertilizers (Toth et al., 2016). The concentrations of $\mathrm{Cd}$ ranged between $(0.01-0.53 \mathrm{mg} / \mathrm{kg})$ are quite similar to the results of Ergul et al. (2008). The highest amount $0.53 \mathrm{mg} / \mathrm{kg}$ was found at impacted site during post-monsoon (Table III). But higher amount of $\mathrm{Cd}$ was found by Ahmad et al. (2010) and Begum et al. (2009). Guideline values for $\mathrm{Cd}$ in is soils shown in Table IV.

\section{Correlation matrix}

The interrelationship among soil variables found in the present study was measured at different significant levels (Bhuyan and Bakar, 2017; Bhuyan et al., 2017). Very strong positive correlation between Cr vs EC (0.965), Cd vs EC (0.962), Cd vs Cr (0.959) and bulk density vs \% sand (0.951) was observed at the significance level 0.01 (Table V). The

Table III. Heavy metal concentrations (mg/kg) in sediment of the Meghna River

\begin{tabular}{llccccc}
\hline & & $\mathrm{Fe}$ & $\mathrm{Pb}$ & $\mathrm{Cr}$ & $\mathrm{Co}$ & $\mathrm{Cd}$ \\
\hline \multirow{3}{*}{ Monsoon } & Polluted & 737 & 6.75 & 2.69 & 0.59 & 0.01 \\
& Non - & & & & & \\
& polluted & 1165 & 2.35 & 1.27 & 0.2 & 0.02 \\
& Polluted & 2385 & 6.98 & 6.81 & 0.86 & 0.53 \\
Post - & Non - & & & & & \\
monsoon & polluted & 1778 & 2.73 & 1.86 & 0.81 & 0.01 \\
& Polluted & 1065 & 5.1 & 2.42 & 0.27 & 0.01 \\
Pre - & Non - & & & & & \\
monsoon & polluted & 1047 & 5.18 & 1.47 & 0.67 & 0.02 \\
& & & & & & \\
\hline
\end{tabular}


result also similar to the results stated by NRCCA (2010). \% Sand vs \% silt $(-0.990)$ and bulk density vs clay $(-0.948)$ showed very strong negative correlations at the $1 \%$ level of significance (Table V). Very strong positive correlations were found between Fe vs \% Sand (0.944), Cd vs Fe (0.824), $\mathrm{Pb}$ vs \% O.M (0.823) and bulk density vs Fe (0.822) at 0.05 level of significance (Table IV). Bulk density vs \% silt $(-0.899)$ and $\mathrm{Fe}$ vs \% silt (-0.842) exhibited strong negative correlation at the alpha level 0.05 (Table V). These results are similar to the results found by NRCCA (2010).
Spatial and temporal changes in soil quality indicators

Significant differences $(\mathrm{p}<0.05)$ was found in the values of soil organic matter of the Meghna river in terms of sites (Fig. 2). But the value of silt, sand, clay, bulk density, $\mathrm{pH}$ and EC exhibited no significant variation with sites ( $p>0.05)$. The concentration of silt, sand, clay, bulk density, $\mathrm{pH}, \mathrm{EC}$ and organic matter showed no significant variations with seasons $(\mathrm{p}>0.05)$.

Table IV. Threshold and guideline values for metals in soils (extract; MEF, 2007)

\begin{tabular}{cccc}
\hline Metal & Threshold value $\mathrm{mg} / \mathrm{kg}$ & $\begin{array}{c}\text { Lower } \\
\text { guideline value } \mathrm{mg} / \mathrm{kg}\end{array}$ & $\begin{array}{c}\text { Higher } \\
\text { guideline value } \mathrm{mg} / \mathrm{kg}\end{array}$ \\
\hline Iron $(\mathrm{Fe})$ & - & - & - \\
Lead $(\mathrm{Pb})$ & 60 & $200(\mathrm{t})$ & $750(\mathrm{e})$ \\
Chromium $(\mathrm{Cr})$ & 100 & $200(\mathrm{e})$ & $300(\mathrm{e})$ \\
Cobalt $(\mathrm{Co})(\mathrm{p})$ & 20 & $100(\mathrm{e})$ & $250(\mathrm{e})$ \\
Cadmium $(\mathrm{Cd})$ & 1 & $10(\mathrm{e})$ & $20(\mathrm{e})$ \\
\hline
\end{tabular}

Ecological risks (e) Health risks (t)

Table V. Correlation among the soil quality parameters

\begin{tabular}{|c|c|c|c|c|c|c|c|c|c|c|c|c|}
\hline Correlations & \% Silt & $\%$ Sand & $\%$ Clay & Bulk Density & $\mathrm{pH}$ & $\mathrm{EC}$ & \% O.M & $\mathrm{Fe}$ & $\mathrm{Pb}$ & $\mathrm{Cr}$ & $\mathrm{Co}$ & $\mathrm{Cd}$ \\
\hline \% Silt & 1 & & & & & & & & & & & \\
\hline \% Sand & $-0.990^{* *}$ & 1 & & & & & & & & & & \\
\hline \% Clay & 0.721 & -0.811 & 1 & & & & & & & & & \\
\hline Bulk Density & $-0.899^{*}$ & $0.951^{* *}$ & $-0.948^{* *}$ & 1 & & & & & & & & \\
\hline $\mathrm{pH}$ & 0.184 & -0.170 & 0.072 & -0.076 & 1 & & & & & & & \\
\hline $\mathrm{EC}$ & -0.502 & 0.528 & -0.518 & 0.592 & 0.424 & 1 & & & & & & \\
\hline \% O.M & 0.329 & -0.252 & -0.127 & -0.029 & 0.797 & 0.491 & 1 & & & & & \\
\hline $\mathrm{Fe}$ & $-0.842^{*}$ & $0.844^{*}$ & -0.658 & $0.822^{*}$ & 0.244 & 0.804 & 0.057 & 1 & & & & \\
\hline $\mathrm{Pb}$ & 0.421 & -0.403 & 0.236 & -0.286 & 0.741 & 0.551 & $0.823^{*}$ & 0.072 & 1 & & & \\
\hline $\mathrm{Cr}$ & -0.363 & 0.396 & -0.442 & 0.490 & 0.643 & $0.965^{* *}$ & 0.665 & 0.739 & 0.677 & 1 & & \\
\hline $\mathrm{Co}$ & -0.216 & 0.182 & 0.002 & 0.150 & 0.632 & 0.432 & 0.182 & 0.617 & 0.383 & 0.522 & 1 & \\
\hline $\mathrm{Cd}$ & -0.540 & 0.543 & -0.431 & 0.557 & 0.541 & $0.962^{* *}$ & 0.473 & $0.824^{*}$ & 0.528 & $0.959^{* *}$ & 0.517 & 1 \\
\hline
\end{tabular}

**. Correlation is significant at the 0.01 level (2-tailed).

*. Correlation is significant at the 0.05 level (2-tailed). 


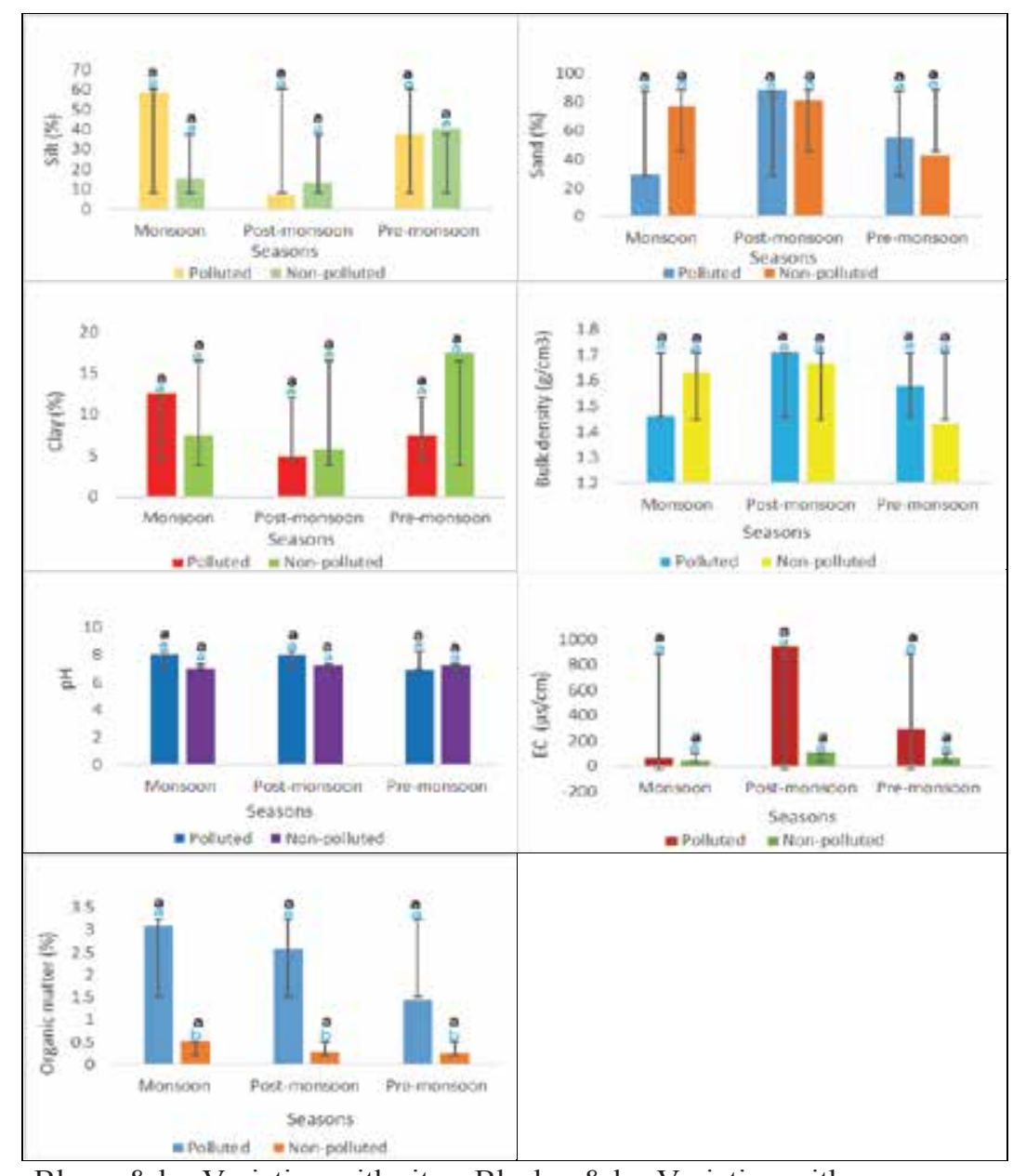

Blue $a \mathrm{\&}=$ Variation with sites, Black $\mathrm{a} \& \mathrm{~b}=$ Variation with seasons

Fig. 2. Variations (Mean \pm SD) of soil quality parameters. Bars with the same letter are statistically indifferent

\section{Conclusion}

Optimum growth of species (both plant and fish) in the Meghna River depend mainly on the finest level of sediment and water quality variables. The present study on soil quality parameters revealed that the surrounding areas were polluted and detrimental for aquatic ecosystem. Anthropogenic sources (industrial and agricultural activities) are the prime responsible factor for river health deterioration. Industries should use the effluent treatment plant (ETP) before discharged their effluents into the river. Proper monitoring of the river by the Government need to be implemented. The government agencies, private agencies and scientists should work together to protect the river with proper attention.

\section{Acknowledgements}

The authors are thankful to the Department of Soil Science, University of Chittagong for giving the facility to conduct test of the soil quality parameters. The authors are also grateful to the Bangladesh Council of Scientific and Industrial Research (BCSIR), Chittagong for making the research facilities available.

\section{References}

Abawi GS and Widmer TL (2000), Impact of Soil Health Management Practices on Soil Borne pathogens, Nematodes and Root Disease of Vegetable Crops, Appl. Soil Ecolo. 15: 37-47.

Ahmad MK, Islam S, Rahman S, Haque MR and Islam MM (2010), Heavy Metals in Water, Sediment and Some Fishes of Buriganga River, Bangladesh, Int. J. Environ. Res. 4: 321-332.

Andrews SS and Carroll CR (2001), Designing a Soil Quality Assessment Tool for Sustainable Agro ecosystem Management, Ecolo. Applica. 11: 1573-1585. 
Andrews KDL and Combardella CA (2004), The Soil Management Assessment Framework: A Quantitative Soil Quality Evaluation Method, SSSA Journal 68: 1945-1962.

APHA (American Public Health Association) (1995), Standard Methods for the Examination of Water and Waste Water, 19 ${ }^{\text {th }}$ Ed., Washington DC, USA, p 1019.

ATDSR (United States Agency for Toxic Substances and Disease Registry) (2007), Toxicological Profile for Lead, U.S. Department of Health and Human Services, p 582.

ATSDR (United States Agency for Toxic Substances and Disease Registry) (2004), Toxicological Profile for Cobalt, U.S. Department of Health and Human Services, p 486.

Balkis N, Topcuoglu S, Guven KC, Ozturk B, Topaloglu B, Kirbasoglu C and Aksu A (2007), Heavy metals in shallow sediments from the Black Sea, Marmara Sea and Aegean Sea regions of Turkey, J. Black Sea/Mediterranean Environ. 13: 147-153.

Balkis N, Aksu A, Okus E and Apak R (2010), Heavy metal concentrations in water, suspended matter, and sediment from Gokova Bay, Turkey, Environ. Monitor. Asses. 167: 359-370.

Balkhair KS, Ashraf MA (2016), Field accumulation risks of heavy metals in soil and vegetable crop irrigated with sewage water in western region of Saudi Arabia, Saudi J. Biolo. Sci. 23: S32-S44.

Barua P and Zamal H (2011), Nutrient dynamics for coastal aquaculture of Bangladesh, Lap Lambert Publishing, p 219.

Benning TL and Seastedt T (1995), Effects of fire, mowing and nitrogen addition on root characteristics in tall-grass prairie, J. Vegeta. Sci. 8: 541-546.

Begum A, HariKrishna S and Khan I (2009) Analysis of Heavy metals in Water, Sediments and Fish samples of Madivala Lakes of Bangalore, Karnataka, Inter. J. Chem. Tech. Res. 1: 245-249.

Bhuyan MS and Bakar MA (2017), Seasonal variation of heavy metals in water and sediments in the Halda River, Chittagong, Bangladesh, Environ. Sci. Pollut. Res. 35: 27587-27600.

Bhuyan MS, Bakar MA, Akhtar A, Hossain MB, Ali MM and Islam MS (2017), Heavy Metal Contamination in Surface Water and Sediment of the Meghna River, Bangladesh, Environ. Nanotech. Monitor. Manag. 8: 273-279.

Boyd CE (1995), Bottom Soils, Sediment, and Pond Aquaculture, Chapman and Hall, New York, p 348.
Bone J, Baraclough D, Archer M and Scheib CF (2010), Soil Quality Assessment under Emerging Regulatory Requirements, Center for Environmental Policy, Imperial College, London.

Bouyoucos GJ (1936), Directions for Making Mechanical Analysis of Soils by the Hydrometer Method, Soil Sci. 42: 3 .

Brady NC and Weil RR (1996), The Nature and Properties of Soils, Prentice-Hall Inc.

Cass A (1986), Irrigation Return Flow Water Quantity and Quality Modelling in South Africa, Dept. of Soil Science, University of Natal, Pietermaritzburg, South Africa, p 110.

CFA (California Fertilizer Association) (1995), Western Fertilizer Handbook, $8^{\text {th }}$ Ed., California Fertilizer Association, Interstate Publishers, Inc. Danville, Illinois, p 338.

Cadisch G, Imhof H, Urquiaga S, Boddey RM, Giller KE (1996), Carbon turnover (delta super (13) C) and nitrogen mineralization potential of particulate light soil organic matter after rain forest clearing, Soil Biolo. Biochemis. 28: 1555-1567.

Camargo JA, Alonso A and Salamanca A (2005), Nitrate toxicity to aquatic animals: a review with new data for freshwater invertebrates, Chemosphere. 58: 1255-1267.

Colt JE and Armstrong DA (1981), Nitrogen toxicity to crustaceans, fish, and molluscs In: Proc. Bio-engineering Symposium for Fish Culture, American Fisheries Society, Bethesda, MD, Eds. Allen LJ and Kinney EC, pp 34-37.

Cragin F (2013), Soil basics | Cooperative Extension. https://extension.unh.edu/Soil-basics

Dar MA (2014), Distribution patterns of some heavy metals in the surface sediment fractions at northern Safaga Bay, Red Sea, Egypt, Arab. J. Geosci. 7: 55-67.

Dexter AR (2004), Soil physical quality Part I. Theory, effects of soil texture, density, and organic matter, and effects on root growth, Geoderma 120: 201-214.

Dexter AR and Bird NRA (2001), Methods for predicting the optimum and the range of water contents for tillage based on the water retention curve, Soil Tillage Res. 57: 203-212.

Doran JW, Sarrantonio M, Liebig M (1996), Soil health and sustainability In: Advances in Agronomy, Ed. Sparks DL, Academic Press, San Diego, 56: 1-54.

Doran JW and Zeiss MR (2000), Soil health and sustainability: Managing the biotic component of soil quality, Appli. Soil Ecolo. 15: 3-11. 
Ergul HA, Topcuoglu S, Olmez E and Kırbaşoglu C (2008), Heavy metals in sinking particles and bottom sediments from the eastern Turkish coast of the Black Sea, Estuar. Coast. Shelf Sci. 78: 396-402.

Giller KE and Cadisch G (1997), Driven by nature a sense of arrival or departure In: Driven by nature plant litter quality and composition, Eds. Cadisch G, Giller KE, CAB International, Wallingford, UK, p 393-399.

Hale C (2013), Earthworms of the Great Lakes, Kollath-Stensaas Publishers, p 47.

Hall GC and Du Plessis HM (1979), The Effects of Irrigation in the Upper Reaches of the Sundays River on Chloride Concentration in Lake Mentz - A Rough Estimate, WRC Co-ordinating Research and Development Committee for Water Quality report, Water Research Commission, Pretoria, South Africa, p 120.

Hossain MB, Marshall DJ and Venkatramanan S (2014), Sediment granulometry and organic matter content in the intertidal zone of the Sungai Brunei estuarine system, Northwest coast of Borneo, Carpath. J. Earth Environ. Sci. 9: 231-239.

Hou Q, Yang Z, Ji J, Yu T, Chen G, Li J, Xia X, Zhang M and Yuan X (2014), Annual net input fluxes of heavy metals of the agro-ecosystem in the Yangtze River delta, China, J. Geochem. Explor. 139: 68-84. DOI: 10.1016/j.gexplo.2013.08.007

Hedlund A, Witter E and Xuan An B (2003), Assessment of $\mathrm{N}, \mathrm{P}$ and $\mathrm{K}$ Management by Nutrient Balance and Flows on peri-urban Small Holders Farms in Southern Vietnam, European J. Agro. 20: 71-87. DOI: 10.1016/S1161-0301(03)00076-5

Huq SMI and Alam MD (2005), A Handbook on Analyses of Soil, Plant, and Water. BACER-DU, University of Dhaka, Dhaka, pp 1-246.

Larson WE and Pierce FJ (1991), Conservation and enhancement of soil quality In: Evaluation for Sustainable Land Management in the Developing World, Vol. 2: Technical papers. Bangkok, Thailand: International Board for Research and Management, 1991. IBSRAM Proceedings No. 12(2), p 175-203.

IARC (2006), Inorganic and organic lead compounds, IARC Monographs on the Evaluation of Carcinogenic Risks to Human, Vol. 87, p 519.

Idowu OY and Van EH (2007), The new Cornell soil health test: Protocols and interpretation. What's cropping up? 17: 6-7.

Islam MS, Tarek MH, Bhuyan MS and Zamal H (2016), Assessment of Soil Quality of Coastal Shrimp Culture Pond at Chakaria, Cox's Bazar, J. Asiat. Soc. Bangladesh Sci. 42: 21-27.
Islam MR, Das NG, Barua P, Hossain MB, Venkatramanan S and Chung SY (2015), Environmental assessment of water and soil contamination in Rajakhali Canal of Karnaphuli River (Bangladesh) impacted by anthropogenic influences: a preliminary case study, Appli. Water Sci. 41: 1-14. DOI: 10.1007/s13201-015-0310-2

Jenny H (1941), Factors of Soil Formation, McGraw-Hill.

Karlen DL, Doran JW and Harris RI (1997), Soil quality a concept definition and framework for evaluation, Soil Sci. Soc. Am J. 61: 4-10. DOI: 10.2136/sssaj1997.03615995006100010001x

Kong XB (2014), China must protect high-quality arable land, Nature 506: 7. DOI: 10.1038/506007a

Lal R, Blum WEH, Allentin C and Stewart BA (1997), Methods for Assessment of Land Degradation, Boca Raton: CRC.

Lal R and Stewart BA (1995), Soil Management Experimental Basis for Sustainability and Environmental Quality In: Advance in Soil Science, CRC Press, Boca Raton, Florida.

Liebig MA, Doran JW and Gardner JC (1996), Evaluation of a field test Kit for measuring selected soil quality : indicators, Agronomy J. 88: 683-686. DOI: 10.2134/agronj1996.00021962008800040030x

Loveland P and Webb J (2003), Is there a critical level of organic matter in the agricultural soils of temperate regions: a review, Soil Tillage Res. 70: 1-18. DOI: 10.1016/S0167-1987(02)00139-3

Luo D, Zheng H, Chen Y, Wang G and Ding F (2010), Transfer characteristics of cobalt from soil to crops in the suburban areas of Fujian Province, Southeast China, J. Environ. Manag. 91: 2248-2253. DOI: 10.1007/s12517-012-0759-3

Machender G, Dhakate R, Rao SM, Rao BM and Prasanna L (2014), Heavy metal contamination in sediments of Balanagar industrial area, Hyderabad, Andhra Pradesh, India, Arabian J. Geosci. 7: 513-525. DOI: 10.1007/s12517-012-0759-3

MEF (Ministry of the Environment, Finland) (2007), Government Decree on the Assessment of Soil Contamination and Remediation Needs (214/2007, March 1, 2007). DOI: 10.1016/j.jenvman.2008.11.002

Mondol MN, Chamon AS, Faiz B and Elahi SF (2013), Chromium in Urban Soil-Plant-Water Ecosystems, $J$. Bangladesh Acad. Sci. 37: 173-187 DOI: 10.3329/jbas.v37i2.17558

Njoku JD (2013), Agro-Ecological Assessment of Soil Quality of a River Watershed in the Niger Delta Region of Nigeria, J. Environ. Earth Sci. 3: 48-56. DI: 
Northeast Region Certified Crop Adviser (NRCCA) Study Resources (2010), Soil and water management, p 74.

Onweremadu EU, Okoli IC, Emenalom OO, Opara MN and Eshett ET (2006), Soil quality evaluation in rangeland soils in relation to heavy metals pollution, Estud. Biol. 28: 37-50. DOI: 10.7213/reb.v28i63.22722

Onweremadu EU (2007), Soil mercury distribution in a forest - savanna mosaic in relation to soil fertility, Res. $J$. Environ. Toxico. 1: 158-166.

Pagliai M and Vignozzi N (2002), Soil pore system as an indicator of soil quality In: Sustainable Land Management-Environmental Protection-A Soil Physical Approach, Eds. Pagliai M and Jones R, Advances in GeoEco. 35: 71-82.

Pagilla K and Canter L (1999), Laboratory studies on remediation of chromium-contaminated Soils, $J$. Environ. Eng. 125: 243-248. DOI: 10.1061/(ASCE)0733-9372(1999)125:3(243)

Palmer CD and Wittbrod PR (1991), Processes affecting the remediation of chromium contaminated sites, Environ. Health Perspect. 92: 25-40.

Parpendick RI and Rarr J (1992), Soil Quality, the Key to Sustainable Agriculturae. Am. J. Alternative Agricul. 7: 2-3.

Rahman K (1992), Industrial pollution and control for sustainable development, Training Manual on Environmental Management in Bangladesh, DoE, Dhaka, p 184-206.

Rajganapathi VC, Jitheshkumar N, Sundararajan M, Bhat KH and Velusamy S (2013), Grain size analysis and characterization of sedimentary environment along Thiruchendur coast, Tamilnadu, India, Arab J Geosci. 6: $4717-4728$.

Rensburg LDV, Clercq WPV, Barnard JD and Preez CCD (2011), Salinity guidelines for irrigation: Case studies from Water Research Commission projects along the Lower Vaal, Riet, Berg and Breede Rivers, Water SA. 37: 739-750.

Riley J (2001), The Indicator Explosion Local Needs and International Challenges, Agricul. Ecosys. Environ. 87: 119-120.

Streutker A, Van Vliet N and Molenaar HW (1981), Besproeiing, gewasopbrengs en dreinering op die Vaalhartsbesproeiingskema: 2. Die voorkoms van verbrakte grond en die invloed van dreinering daarop., Water SA. 7: 175-184.

Suresh KR and Nagesh MA (2015), Experimental Studies on Effect of Water and Soil quality on Crop Yield, Aqua Procedia. 4: 1235-1242. DOI: 10.1016/j.aqpro.2015.02.161
Topcuoglu S, Olmez E, Kirbasoglu C, Y1lmaz YZ and Saygın N (2004), Heavy metal and radioactivity in biota and sediment samples collected from Ünye in the eastern Black Sea In: Proc. $37^{\text {th }}$ CIESM (Commission Internationale pour exploration Scientifique de la Mer Mediterrane'e) Congress, Barcelona, Spain, p 250.

Toth G, Hermann T, Da Silva MR, Montanarella L (2016), Heavy metals in agricultural soils of the European Union with implications for food safety, Environ. Intern. 88: 299-309. DOI: 10.1016/j.envint.2015.12.017

Toth G, Jones A and Montanarella L (2013), LUCAS Topsoil Survey-methodology, data and results. EUR 26102 EN. Office for Official Publications of the European Communities, Luxembourg, p 141.

Townsend WN (1982), An Introduction to the Scientific Study of the Soil, Edward Amold (Publishers) Ltd., U.K, p 209.

Van Der Merwe AJ (1965), Certain Fundamental Characteristics of Selected Alkali Soils, M.Sc. Agric. Thesis, University of the Free State, Bloemfontein, South Africa, p 109.

Venkatramanan S, Ramkumar T and Anithamary I (2013a), Distribution of grain size, clay mineralogy and organic matter of surface sediments from Tirumalairajanar Estuary, Tamilnadu, east coast of India, Arabian J. Geosci. 6: 1371-1380. DOI: 10.1002/esp.261

Venkatramanan S, Ramkumar T, Anithamary I and Jonathan MP (2013b), Speciation of selected heavy metals geochemistry in surface sediments from Tirumalairajan river estuary, east coast of India, Environ. Monitor. Assess. 185: 6563-6578.

Venkatramanan S, Chung SY, Lee SY and Park N (2014a), Assessment of river water quality via environmentric multivariate statistical tools and water quality index: a case study of Nakdong river basin, Korea, Carpath. $J$. Earth Environ. Sci. 9: 125-132.

Venkatramanan S, Ramkumar T, Anithamary I and Vasudevan S (2014b), Heavy metal distribution in surface sediments of the Tirumalairajan river estuary and the surrounding coastal area, east coast of India, Arabian J. Geosci. 7: 123-130.

Wosten JHM, Lilly A, Nemes A and Le Bas C (1999), Development and use of a database of hydraulic properties of European soils, Geoderma. 90: 169-185. DOI: 10.1016/S0016-7061(98)00132-3

Zhang WL, Tian ZX, Zhang N and Li XQ (1996), Nitrate Pollution of Groundwater in Northern China, Agricul Ecosys \& Environ. 59: 223-231. DOI: 10.1016/0167-8809(96)01052-3 